\title{
Boards Of Advisors In Small Businesses: An Empirical Profile Of Their Composition And Use
}

\author{
Michael D. Akers, (E-mail: Michael.akers@marquette.edu), Marquette University
} Don E. Giacomino, Marquette University

\begin{abstract}
This article discusses the literature coverage on Boards of Advisors to date and provides the results of a study designed to determine the formation and composition of Boards of Advisors and the ways in which small businesses use such boards. Our study surveyed the Chief Executive Officers or Presidents of a large sample of small businesses. We found that there is very limited use of Boards of Advisors in small businesses and that many small business managers are not aware of the concept of a Board of Advisors. However, those small business managers (97\%) that use a Board of Advisors characterize their interaction with their Boards of Advisors as good or excellent. When selecting board members, the responding executives seek practical experience, good "common sense" and industry experience as the most important types of expertise. Most board members were male (67\%), active in business (90\%), have managerial/strategy or law (52\%) and are not compensated (53\%).
\end{abstract}

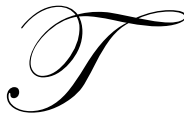

he concept of a Board of Advisors is not new; however there appears to be very limited coverage of the concept in business and academic publications. While some writers have proposed the use of a Board of Advisors for large corporations and small businesses, textbooks on business management are mostly silent about the subject. In addition, academic researchers have conducted very little empirical study on the subject. The main purpose of this article is to describe our recent study on the composition and use of Boards of Advisors by small businesses. In the process, we will also provide an up-to-date coverage of the literature on Boards of Advisors.

In a small business, the management faces most of the same operational problems of large corporations, but the small business usually lacks the staffing to deal with these problems. The President or Chief-Executive-Officer of a small business, often coming from a technical or engineering background might lack the necessary experience in general management. In addition, the firm often has a very small management team, lacking in finance, accounting, marketing or strategy expertise. In this situation, a Board of Advisors, or quasi-board, might prove useful.

A Board of Advisors has some similarity to a Board of Directors, but there are some important differences that make the Board of Advisors an attractive option. The two types of boards are similar in that the boards can offer outside expert advice to management on many strategic and operational issues. However, whereas the stockholders of a large corporation choose the Board of Directors, the management of a small business will choose the members for its Board of Advisors. Thus, the President or Chief-Executive-Officer of a small business can decide which skills and expertise the firm needs most from the advisors. This, in turn, helps direct the choice of advisors. Boards of Directors typically serve as an oversight function and give directions to management, while the Board of Advisors' responsibility is to provide advice, not oversight and direction. Thus, the power relationship between management and the board differs. Management gets to decide which issues need to be addressed by the Board and management is free to accept or reject advice from the Board. Since the main role of the Board of Advisors is advisory, there is also the advantage of little, if any, liability on the part of the advisors. This assumes that the advisors act strictly in an advisory capacity. 

Advisors.

Following is a tabulation of some of the main differences between a Board of Directors and a Board of

Table 1: Board of Directors versus Board of Advisors

\begin{tabular}{lll}
\hline & Directors & Advisors \\
\hline Choice of Members & By shareholders & By Management \\
Purpose & Oversight & Only advisory \\
Oversight & Give directions & Simply advisory \\
Agenda & BOD sets agenda & Management sets agenda \\
Liability & Increasing & Little, if any (assumes only advisory) \\
Responsibility & Directs Management & Advises Management \\
\hline
\end{tabular}

\section{The Literature On Boards Of Advisors}

Some scholars have written papers and made presentations on the benefits of having a Boards of Advisors. Much of that work is anecdotal and dated (written in the early and mid-80's). Most of the works deal with topics such as the guidelines for establishing the board, specific ways in which boards can be used and, to a lesser degree, some of the disadvantages of having a Board of Advisors.

A review of the relevant literature shows that very little empirical work has been done with respect to Boards of Advisors. Morkel and Posner (2002) is the only empirical study that we found. They conducted interviews with 22 individuals to obtain information about the composition and disposition of advisory boards. The study was limited to individuals in the Silicon Valley. Five Chief Executive Officers, twelve previous corporate officers and five university professors who were serving on a Board of Advisors or Board of Directors. Interviewees rated their experiences as board members as follows:

$\begin{array}{lll}\text { - } & \text { Mostly effective or very effective } & 46 \% \\ \text { - } & \text { Average effectiveness } & 26 \% \\ \text { - } & \text { Somewhat or not very effective } & 28 \%\end{array}$

Other than the above statistics on effectiveness, there were no descriptive data on Boards of Advisors from the Morkel and Posner study.

Morkel and Posner found that the CEO was the most important factor in the effectiveness of advisory boards. The attitude and the time and effort of the CEO was crucial to board effectiveness. In addition, the CEO must display qualities of leadership and provide direction, the willingness to open up with problems, to seek advice and to listen. The CEO should not try to "sell' or "sandbag" the board. Based on those interviews, Morkel and Posner concluded that Boards of Advisors could play a useful function.

Morkel and Posner had a few other interesting findings. Most of the advisors who were interviewed in the study said they were on the board because of specific interest in the company or the field (industry). The advisors were recruited to the board through personal acquaintances within the firm and through networking.

\section{Methodology}

First, we conducted a pilot study. This study surveyed the Chief Executive Officers or Presidents of 100 small businesses in Wisconsin. We defined "small businesses" as those between $\$ 20,000,000$ and $\$ 120,000,000$ of revenues. We conducted the study to test the original survey instrument. Second, after revising the survey instrument on the basis of feedback from respondents in the pilot study, we conducted our national study. 
For the national study, we purchased from Dun \& Bradstreet a randomly chosen list of names of 2500 organizations with revenues from $\$ 20,000,000$ to $\$ 120,000,000$. Then, from this list we chose a random sample of 250 firms for each of the following groups in terms of millions of dollars of revenue: 21-30, 31-40, 41-50, 51-60, 61-70, 71-80, 81-90, 91-100, 101-110, 111-120. For each of the 250 small businesses selected, we sent the Chief Executive Officer or President a cover letter and survey questionnaire, as shown in Exhibits A and B.

\section{Results}

We received 258 useable responses for a $10.32 \%$ response rate. Of the 258 responding firms, thirty firms (11.6\%) have an Advisory Board and 228 (88.4\%) firms do not have an Advisory Board. Of the 228 responding firms that do not have an advisory board, 208 have a Board of Directors.

\section{Composition and Size of Boards of Advisors}

We found that of the 258 responding small businesses only thirty have a Board of Advisors. In addition, twenty-five of those companies also have a Board of Directors, with an average size of 9.2 directors. Therefore, just five of the firms have only a Board of Advisors. This is a somewhat surprisingly low figure in light of the apparent advantages and low cost of having a Board of Advisors. A very high percentage (90\%) of the members of the Boards of Advisors are still active in businesses. This suggests the possibility that there might be a good supply of retired business managers who would be available for service on a Board of Advisors. It also suggests, however, that the responding executives prefer to have members who are active in business; since the managers get to choose their board members. Regarding the ethnic makeup of the boards, over $90 \%$ of the members are either Caucasian (77.7\%) or Hispanic (12.8\%). This might reflect the racial distribution among managers, but suggests the potential of including more African American and Asian American members, which make up only 5.7\% and 2.4\%, respectively. Boards of Advisors ranged in size from two to 150, with and average size of 17, and males constituted $67 \%$ of the membership.

Table 2: Composition and Size of Boards

\begin{tabular}{|c|c|c|}
\hline & Freq & $(\%)$ \\
\hline Firms that have a Board of Directors: (Quest. 1): & 25 & $(83.3 \%)$ \\
\hline Average Size of Board of Directors (Quest. 2) & 9.2 & (range 3 to 20 ) \\
\hline Firms that have a Board of Advisors (Quest. 3) & 30 & $(100 \%)$ \\
\hline \multicolumn{3}{|l|}{ Number of advisors in each category (Quest. 5) } \\
\hline & & Percent \\
\hline - Active in Business & & $90.0 \%$ \\
\hline - Retired & & $7.7 \%$ \\
\hline - Former Government Official & & $2.3 \%$ \\
\hline Total & & $\overline{100.0 \%}$ \\
\hline - Caucasian & & $77.7 \%$ \\
\hline - Hispanic & & $12.8 \%$ \\
\hline - African American & & $5.7 \%$ \\
\hline - Asian & & $2.4 \%$ \\
\hline - Non-U.S. Nationals & & $1.4 \%$ \\
\hline Total & & $10 \overline{0.0 \%}$ \\
\hline Size of Board of Advisors (Quest. 10) & Freq & \\
\hline - Average Size & 17 & \\
\hline - Range & $2-150$ & \\
\hline - Average (without 150) & 13 & \\
\hline \multicolumn{3}{|l|}{ Gender of board members (Quest. 11) } \\
\hline - Male & $67 \%$ & \\
\hline - Female & $33 \%$ & \\
\hline
\end{tabular}


Table 3: Formation and Use of Boards

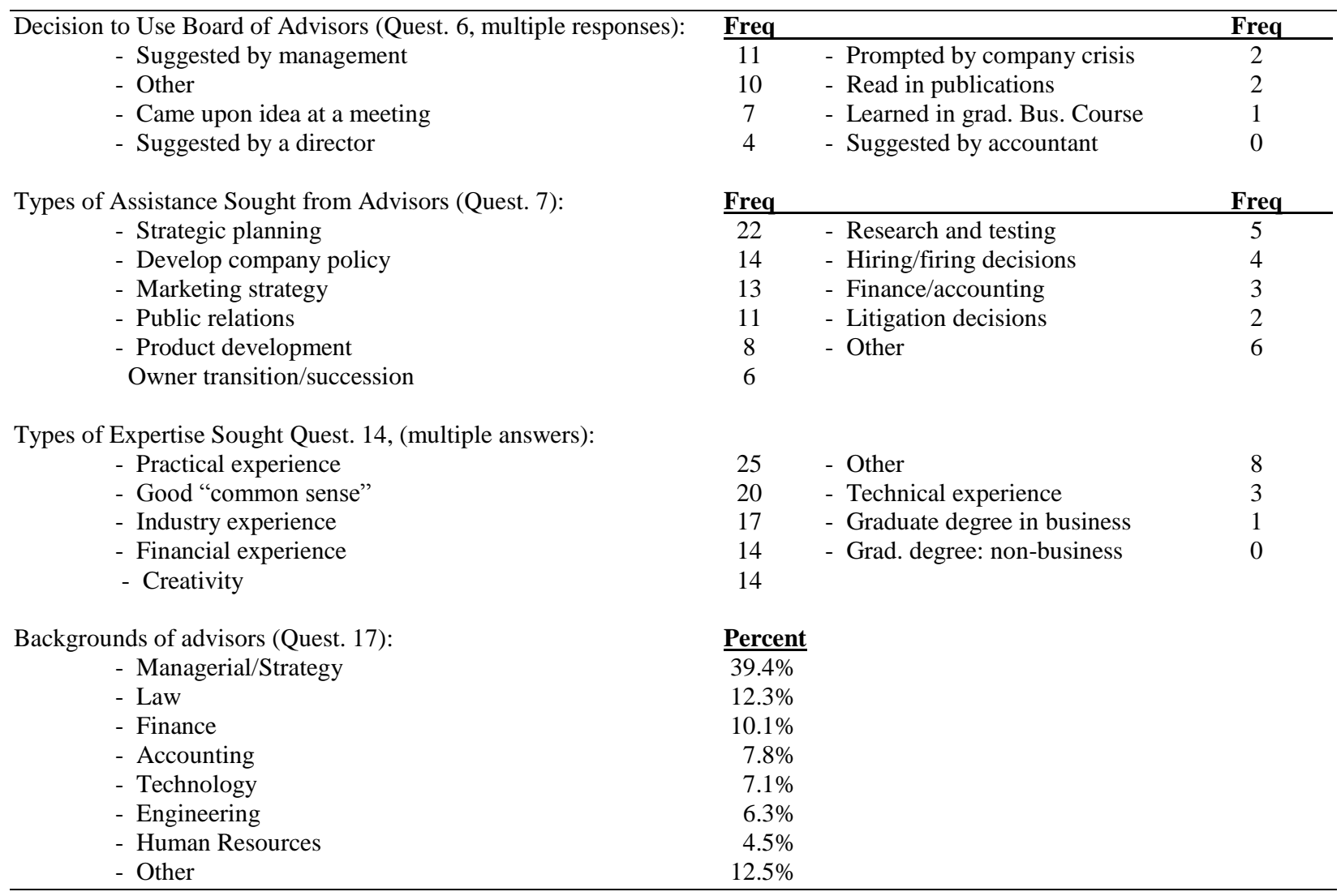

\section{Formation and Use of Boards}

Regarding the decision to use a Board of Advisors, the sources are almost all internally generated. Responding CEOs and Presidents indicated that the most frequent reason was "suggested by management' (11). This is a positive sign since the literature and the study by Morkel and Posner indicate that management's attitude is most critical to effectiveness of a Board of Advisors. Next in frequency were "came upon idea at a meeting" (7) or "suggested by a director" (4).

With regard to the type of assistance that executives seek from board members, responding executives sought assistance on strategic planning (22), developing strategy (14), marketing strategy (13) and public relations (11). One interesting finding was that "finance/accounting" was mentioned infrequently (only 3 times). This might indicate that the managers either feel confident in their finance/accounting abilities or they rely upon their CPA or other financial advisors for such advice. Given the recent SEC requirements for financial expertise on Boards of Directors of publicly traded firms, small businesses might consider including someone with finance and/or accounting expertise on their Boards of Advisors.

Regarding the types of expertise sought from advisors, practicality and relevance to the company and its industry were most important. The executives rated "practical experience" (25) and "good common sense" (20) most frequently. This was followed by "industry experience' (17), "practical experience" (14) and "creativity" (14). 
Managerial/strategy is the most frequently mentioned (39\%) background of the members of the Boards of Advisors. This shows the importance that the responding executives place on getting members who can see the "big picture" and can focus on strategic planning. This is consistent with the results on Question 7, where strategic planning is the most frequently mentioned type of assistance sought from advisors. Apparently, the small business executives are relatively comfortable with their own abilities in the areas of human resources, engineering and technology, since they were mentioned least frequently.

\section{Interaction Between Management and Advisors}

One of the most positive findings from the survey was the response from executives on the interaction between management and the Board of Advisors. Almost all respondents rated this interaction as either "good" $(50 \%)$ or "excellent" $(47 \%)$. This should be encouraging to small businesses that are considering the use of a Board of Advisors. Responding executives cited some problems in working with advisors. Two of the results show the emphasis of management on practicality; "Advisors lack practical expertise (6) and "advisors seem too theoretical" (4). Two other reasons cited on this question also appear to be related: "Advisors don't take time to understand company's problems" (6) and "Advisors too interested in getting business for themselves" (5).

Table 4: Interaction Between Management and Advisors

\begin{tabular}{lcc}
\hline Interaction between advisor and senior management (Quest. 15): & Freq & $(47 \%)$ \\
- Excellent & 14 & $(50 \%)$ \\
- Good & 15 & $(0 \%)$ \\
- Satisfactory & 0 & $(0 \%)$ \\
- Below expected & 0 & $(3 \%)$ \\
- Very poor & 1 & $(0 \%)$ \\
- Too limited & 0 &
\end{tabular}

Problems with advisors (Quest. 16):

- Advisors don't take time to understand company problems

- Advisors lack practical expertise in areas needed

- Advisors too interested in getting business for themselves

- Advisors seem too theoretical (rather than practical)

- Friction between advisors and management

- Other

\begin{tabular}{c} 
Freq \\
\hline 6 \\
6 \\
5 \\
4 \\
2 \\
6
\end{tabular}

\section{Meetings and Compensation}

Most (24) of the responding CEOs and Presidents meet with their Board of Advisors on either a quarterly (17) or annual (7) basis at the company offices. In addition, most companies (53\%) do not compensate their advisors. This is consistent with some of the literature that suggests that most advisors serve because of interest in the company and that advisors should not be compensated. Where advisors are compensated, it is usually (8) in the form of a meeting fee. Stock or stock options are not given to advisors by any of the firms responding to the survey. 
Table 5: Meetings and Compensation

\begin{tabular}{|c|c|}
\hline $\begin{aligned} \text { Frequency of meetings (Quest. 8): } \\
\text { - Annually } \\
\text { - Semi-annually } \\
- \text { Quarterly } \\
\text { - Monthly } \\
\text { - Bi-monthly }\end{aligned}$ & $\begin{array}{c}\text { Freq } \\
3 \\
2 \\
17 \\
7 \\
1\end{array}$ \\
\hline $\begin{aligned} & \text { Location of meetings (Quest. 9): } \\
& \text { - Company offices } \\
& \text { - Local hotel/restaurant } \\
& \text { - Advisor's office } \\
& \text { - Other (Bd. Rm, Tel. Conf., Bus. Club, Convenient Place) }\end{aligned}$ & $\begin{array}{l}\frac{\text { Freq }}{20} \\
7 \\
0 \\
4\end{array}$ \\
\hline $\begin{array}{c}\text { Board members compensated (Quest. 12): } \\
\text { - Yes } \\
\text { - No }\end{array}$ & $\begin{array}{l}\text { Percent } \\
47 \% \\
53 \%\end{array}$ \\
\hline 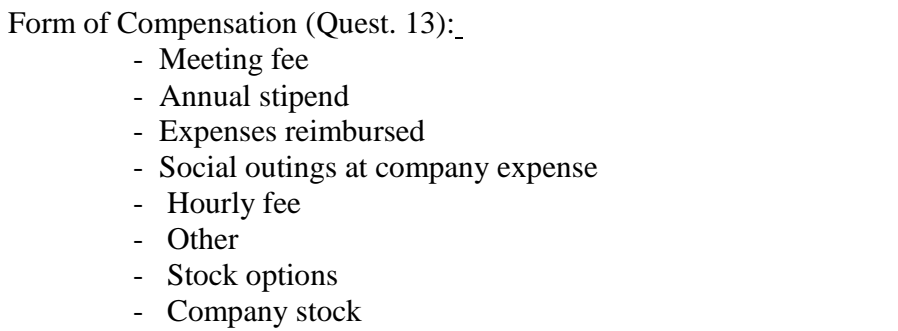 & $\begin{array}{l}\frac{\text { Freq }}{8} \\
4 \\
4 \\
3 \\
0 \\
0 \\
0 \\
0\end{array}$ \\
\hline
\end{tabular}

\section{Conclusion And Recommendations}

The literature on Boards on Boards of Advisors has been sparse, mostly focused on discussing the benefits of Boards of Advisors for large and small firms. Boards of Advisors differ from Boards of Directors with respect to purpose, oversight, formation, liability and responsibilities. Morkel and Posner found that managers whom they interviewed had positive experiences with Boards of Advisors. This study confirms the fact that small businesses make very little use of a Board of Advisors, with only thirty of the 258 responding firms having a Board of Advisors. The main reason cited for this limited use was lack of awareness on the part of managers of small businesses.

This article represents one attempt at reaching small business managers by informing them of the values of Boards of Advisors, providing a profile of the existing Boards of Advisors at small businesses and encouraging promotion and further study of Boards of Advisors. This study examined several aspects of Boards of Advisors, gathering data on size and composition of such boards and how they are used. We found that almost all (97\%) responding small business managers are satisfied with their Board of Advisors, characterizing their relationships with their Board of Advisors as "Good" or "Excellent".

We found that, although the most frequent reason for use of such board was "suggested by management"; the most frequent reason for not having such board was unawareness by management. We also found that $67 \%$ of the members of Boards of Advisors are male, suggesting the potential for including more females. Perhaps, women who have business experience but are no longer in the work force would also be a good source of supply. In addition, retired business managers might also be a good source. Our study did not obtain age of board members: however, since most (53\%) of the firms in our study do not compensate their advisors, retirees, not dependent on income might be good candidates for the boards. These experienced, retired managers might want to keep active and involved by serving as advisors, while avoiding the increasing liability exposure that members of Boards of Directors are facing. 
Small business organizations might consider offering seminars or informational materials describing the nature and purpose of Boards of Advisors. People with experience as members of Boards of Advisors might participate in the design and/or delivery of such programs. In addition, programs on Entrepreneurship might consider covering the topic within their programs.

\title{
Exhibit A
}

Cover Letter

\author{
James L. Beam \\ Chairman of the Board \\ Kentuck Distilleries \\ 1442 Loop Road \\ Derbytown, KY 00000 \\ Dear Mr. Beam:
}

The purpose of this letter is to request your participation in a research study that examines the use of a Board of Advisors by small and medium sized businesses. The enclosed survey is intended to gather information about the use and effectiveness of a Board of Advisors. Results of the study will be the basis of a paper that my colleagues and I will submit to a journal such as The Small Business Journal.

In contrast to an organization's permanent Board of Directors, which establish policy and manage the corporation's affair on behalf of the shareholders, a Board of Advisors is created to provide advice and counsel on any number of issues to the President/CEO and senior management. A Board of Advisors provides essential expertise or critical analysis that might not otherwise be available to the organization. Management can choose either to accept or reject the recommendations/advice of a Board of Advisors whereas management must adhere to the decisions of a Board of Directors.

Your participation in this research project will require no more than 15 minutes of your time to complete the questionnaire. The success of the study depends upon achieving as high a response rate as possible. I would appreciate your attention to this matter and the return of the completed survey in the enclosed self-addressed stamped envelope. Please be assured that your participation in this study is completely confidential.

Thank you for your cooperation and participation in this study. If you desire a copy of the results of this study, please enclose a note with your return correspondence. If you have any questions regarding this project, please feel free to contact me by e-mail at 6320akersm@vms.csd.mu.edu or by phone at (414) 288-1453.

Sincerely,

Michael D. Akers, Ph.D., CPA, CIA, CMA, CFE

Associate Professor and Charles T. Horngren Professor of Accounting 


\section{Exhibit B}

\section{Board of Advisors Survey}

1. Does your company presently have a Board of Directors yes no

2. If yes, how many members are on the board?

3. Does your company have a Board of Advisors? no

4. If no, indicate why by checking each of the following that apply, then stop after this question and return the survey:

not familiar with Board of Advisors concept have not found qualified people to serve on such board reluctant to confide data to outsiders other (specify)

5. If yes, please indicate the number of advisors who are:

former government officials __ active in business Hispanic__Asian ___African American

retired non-U.S. nationals

Caucasian

For companies with a Board of Advisors, please answer the following:

6. How did your company first decide to utilize a Board of Advisors? (check all that apply)

read about idea in trade publication

suggested by a Director suggested by management

learned about idea in graduate business course came upon idea at meeting suggested by accountant _prompted by company crisis other (please specify)

7. What type of assistance does your Board of Advisors provide? (check all that apply)

develop company policy public relations litigation decisions owner transition/succession

$\begin{array}{ll}\text { hiring/firing decision } & \text { _ strategic planning } \\ \text { research and testing } & \text { marketing strategy } \\ \text { finance/accounting } & \text { _ } \\ \text { other (please specify) } & \end{array}$

_hiring/firing decision finance/accounting other (please specify)

8. How often does the Board meet? Annually Quarterly Monthly

9. Where are meetings conducted? other (specify)

Company offices local hotel/restaurant advisor's office

10. What is the size of your Board of Advisors?

11. How many advisors are:___ male ___female

12. Are advisors compensated? __ yes ___ no

13. If advisors are compensated, what is the form?

hourly fee company stock (please specify) _meeting fee ___annual stipend social outings at company expense stock options

expenses reimbursed___other 
14. Which types of expertise does your company feel are most important for board membership? (check all that apply)?

_practical business experience good "common sense" industry expertise graduate degree in business creativity financial expertise graduate degree, non-business technical experience other (specify)

15. How would you characterize interaction between your advisors and senior management?

Excellent ___ Good ___Satisfactory ___Below Expected ___Very Poor__Too Limited

16. Which problems have encountered with your board? (check all that apply)

Advisors too interested in getting business for themselves than in providing assistance to company

Advisors do not take time to understand company's problems

Advisors lack practical expertise in areas needed by the company

Advisors seem too theoretical (rather than practical)

Friction between advisors and management make ideas unworkable other (please specify)

17. Please indicate the number of advisors who have the following backgrounds:

$\begin{array}{ll}\text { Accounting } \_ \text {Finance } & \text { Engineering } \\ \text { Law } & \text { Human Resources } \_ \text {Technology } \\ \text { Managerial/Strategic } & \text { Other (please specify) } \_\end{array}$


Notes 